\title{
HEZBOLLAH - ÎNTRE MIT ȘI REALITATE
}

Daniel ȘOIMARU*

Hezbollah este un actor nestatal cu o influență decisivă asupra modului in care evoluează dinamicile politice și de securitate din Liban, având un rol important in cadrul complexului regional de securitate din Orientul Mijlociu. $\mathrm{Cu}$ toate acestea, pentru a putea ințelege comportamentul acestui actor, este necesară evidențierea principalelor sale caracteristici ideologice. Prin urmare, intrebarea de cercetare care a permis materializarea acestui studiu este: Cum a influențat ideologia asumată de către liderii Hezbollah comportamentul organizației? Prin intermediul acestui studiu dorim să evidențiem contextul istoric al Libanului în perioada anilor 1980, precum și să analizăm principalii factori care au determinat materializarea Hezbollah. De asemenea, vrem să ințelegem principalii piloni ideologici ai Hezbollah și modul în care aceștia au influențat obiectivele și acțiunile organizației și să examinăm modul în care statele vestice percep activitatea desfășurată de Hezbollah. Totodată, ne propunem să analizăm relația dintre Iran și Hezbollah din perspectiva motivațiilor și intereselor pe care decidenții politici de la Teheran le au în raport cu creșterea influenței iraniene în Orientul Mijlociu.

Cuvinte-cheie: Hezbollah; complexul regional de securitate din Orientul Mijlociu; strategie; terorism; Iran; Israel.

\section{Introducere}

Din punctul de vedere al dinamicilor de securitate, Orientul Mijlociu are o trăsătură unică, fiind caracterizat de o stare structurală de insecuritate, fapt care i-a determinat pe specialiștii în relații internaționale să afirme că această regiune reprezintă un „vulcan din punct de vedere geopolitic (...) ale cărei neîntrerupte

* Daniel ŞOIMARU este masterand în domeniul Leadership și comunicare în organizații internaționale, Facultatea de Istorie și Filosofie, Universitatea Babeș Bolyai, Cluj-Napoca.E-mail: dani.soimaru@gmail.com 
erupții (...) destabilizează regiunea (...) și îl transformă în cel mai virulent focar de războaie religioase civile și/sau interstatale și teroriste" ${ }^{\text {. }}$ De aceea, una dintre problematicile de cercetare privind complexul regional de securitate din Orientul Mijlociu este reprezentată de modul în care organizaţiile teroriste religioase au reuşit să destabilizeze această regiune. Pentru o mai bună claritate conceptuală, trebuie precizat faptul că termenul de terorism religios implică o categorie distinctă de violență politică, comisă în numele religiei, de către militanți motivați religios. ${ }^{2}$ Hezbollah (Partidul lui Allah) reprezintă o astfel de entitate religioasă, care are o influență crucială asupra modului în care evoluează dinamicile politice și de securitate în Liban, având în același timp și un impact important asupra complexului regional de securitate din Orientul Mijlociu.

Prin intermediul acestei lucrări, dorim să evidențiem principalele particularități ideologice ale Hezbollah, modul în care liderii organizației percep acțiunile acesteia, precum și poziţionarea statelor occidentale în raport cu acest actor nestatal. În acest sens, cercetarea prin intermediul căreia a fost materializat acest studiu, a fost concentrată asupra modului în care ideologia asumată de către liderii Hezbollah a influențat comportamentul organizației. Metodologia de cercetare utilizată este reprezentată de o abordare sistematică care are o dublă dimensiune, cea a narațiunii istorice (din perspectiva factorilor care au favorizat emergența organizației Hezbollah) și cea analitică (prezentarea modului în care pilonii ideologici ai Hezbollah au influențat acțiunile organizației; analizarea poziționării statelor occidentale privind acțiunile Hezbollah; evidențierea particularităților strategice privind relația Iranului cu Hezbollah). Sursele principale utilizate în cadrul acestei cercetări au fost documente oficiale, discursuri ale unor decidenți politici și militari, precum și cărți și articole de specialitate pe acest subiect.

Lucrarea este împărțită în patru secțiuni principale. Astfel, în cadrul primei părți este prezentat contextul istoric al Libanului din perioada anilor 1980, analizând factorii principali care au determinat materializarea organizației Hezbollah. A doua parte a studiului evidențiază principalii piloni ideologici ai Hezbollah și cum aceștia au influențat obiectivele și acțiunile organizației. A treia parte a lucrării examinează modul în care Hezbollah și statele occidentale se percep reciproc. Astfel, această secțiune analizează strategiile liderilor Hezbollah de a construi o imagine moderată a organizației în cadrul comunității internaționale, precum și atitudinea liderilor occidentali care nu reușesc să înțeleagă acest mecanism de manipulare. În cadrul ultimei secțiuni este prezentată relația dintre Iran și Hezbollah, din perspectiva motivațiilor și intereselor decidenților politici de la Teheran în Orientul Mijlociu.

\footnotetext{
${ }^{1}$ Pascal Lamy, Nicole Gnesotto, Jean Michel Baerm, Where is the world going?, Editura Niculescu, București, 2018, p. 105.

${ }^{2}$ Gunning Jeroen, Jackson Richard, „What's so religious about „religious terrorism”, în Critical Studies on Terrorism, 2011, pp. 369-388.
} 


\section{Factorii care au favorizat apariția și emergența Hezbollah}

Analizând evoluția organizațiilor radicale religioase, poate fi sesizat faptul că acestea au început să-și mărească influența în lumea arabă începând cu sfârșitul anilor 1970 și au reușit să-și consolideze prezența începând cu anii 1990. Această vitalizare a fost însoțită de o resurgență islamică la nivel global. ${ }^{3}$ Ascensiunea mișcărilor islamiste, în general, și a Hezbollah, în particular, s-a datorat contextului socio-politic din Orientul Mijlociu: înfrângerea statelor arabe de către Israel, eșecul realizării unei dezvoltări socio-economice echilibrate, omniprezența opresiunii politice, distribuirea inegală a bogăției, impactul psiho-cultural al occidentalizării etc. $^{4}$

Această stare de fapt a contribuit la creșterea clivajelor politice și sociale din Liban, conducând la izbucnirea Războiului Civil din 1975. Din punct de vedere al milițiilor șiite implicate în conflict, organizația Amal, condusă de către Musa al-Sadr, a avut rolul cel mai important. Cu toate acestea, această organizație a fost doar primul prototip, ulterior fiind asimilată de către Hezbollah, care i-a depăşit cu mult performanțele.

Unul dintre principalii factori care au determinat emergența organizației teroriste Hezbollah a constat în reorientarea politicii externe și de securitate a Iranului, după Revoluția Islamică din 1979. Astfel, din 1979, Iranul reprezintă unul dintre cei mai activi sponsori globali ai terorismului. Liderii iranieni au încercat să controleze comunităţile șiite din statele aflate în proximitatea Iranului, oferindu-le arme, pregătire militară și inspirație. ${ }^{5}$ Prin urmare, având în vedere importanța geopolitică a Libanului (acces la Marea Mediterană și poziționat în vecinătatea nordică a Israelului), dar și a faptului că sudul țării este populat de către o populație majoritar șiită, liderii iranieni au vrut să controleze această regiune prin intermediul unui agent proxy.

Un alt aspect important care a permis emergența organizației Hezbollah a fost reprezentat de invazia Libanului, de către trupele militare israeliene, în iunie 1982. Principalele obiective ale invaziei au fost reprezentate de dorința decidenților politici și militari israelieni de eliminare a infrastructurii Organizației pentru Eliberarea Palestinei din sudul Libanului și retragerea trupelor siriene de pe teritoriul libanez. Armata israeliană a reușit să se impună determinând eradicarea Organizației pentru Eliberarea Palestinei din Liban, dar a contribuit la radicalizarea comunităţii șiite din acest stat (care iniţial a sprijinit invazia israeliană, deoarece palestinienii au

${ }^{3}$ Rosita Di Peri, „Islamist Actors from an Anti-system Perspective: The Case of Hizbullah”, în Politics Religion and Ideology, vol. 15, nr. 4, 2014, pp. 487-503.

${ }^{4}$ Ibidem.

${ }^{5}$ Daniel Byman, Deadly Conections States that Sponsor Terrorism, Cambridge University Press, 2005, p. 79. 
fost percepuți ca fiind un factor de instabilitate, dar odată cu prelungirea invaziei s-au întors împotriva Israelului) contribuind la emergența organizației teroriste Hezbollah. ${ }^{6}$ In contextul invaziei israeliene din Liban, Hezbollah a apărut ca rezultat al unificării mai multor grupuri de militanți șiiți (clerici, membri ai partidului Da 'wa și disidenți din cadrul grupării Amal), care doreau să lupte împotriva Israelului. ${ }^{7}$ Detașarea a 1.500 de soldați ai Gărzii Revoluționare Iraniene în regiunea Biqa (controlată de către Siria), în vara anului 1982, sub pretextul luptei împotriva Israelului, a facilitat începutul prezenței militare a Iranului în Liban. Astfel, înțelegerea dintre Iran și Siria asupra staționării Gărzilor Revoluționare în Liban a reprezentat un factor decisiv privind expansiunea Hezbollah. ${ }^{8}$

De asemenea, un alt factor care a permis materializarea Hezbollah a fost generat de lipsa unor instituții puternice în Liban care să asigure coeziunea statului. În cazul Libanului, loialitatea cetățenilor este conferită de apartenența la un anumit grup religios, determinând fragmentarea societăţii civile. Mai mult decât atât, sistemul politic libanez a fost implementat pe baza unui compromis care prevede faptul că, fiecare grup religios important din Liban trebuie să fie reprezentat în structurile de conducere a statului. Ambele reprezintă vulnerabilitătị pe care organizația Hezbollah a reușit să le exploateze în interesul său și, fără posibilitatea intervenției străine, există puține șanse să renunțe la a face aceasta.

Cu toate acestea, Hezbollah a așteptat până în anul 1984 să declare public crearea sa, prin intermediul unui comunicat în cadrul celei de-a doua manifestări de comemorare a masacrelor de la Sabra şi Shatilla, promițând faptul că această organizație „continuă marșul pentru eliberarea Palestinei”" În februarie 1985, Hezbollah a adoptat în mod oficial manifestul politic al organizației, menționând caracteristicile mișcării: Islamul reprezintă singura soluție de a scoate lumea din întuneric și necesitatea declarării Jihadului împotriva influenței occidentale și a Uniunii Sovietice. ${ }^{10}$

\section{Pilonii Hezbollah}

Pentru a înțelege motivațiile și acțiunile Hezbollah, trebuie să identificăm principalele coordonate ideologice ale organizației. Potrivit lui Naim Qassem ${ }^{6}$ Ibidem.

${ }^{7}$ Daniel Meler, „(B)ordering South Lebanon: Hizbullah`s Identity Building Strategy”, în Journal of Borderlands Studies, 2015, pp. 1-13.

${ }^{8}$ Nizar Hamzeh, „Lebanon`s Hizbullah: From Islamic Revolution to Parliamentary Accommodation”, în Third World Quarterly, vol. 14, nr. 2, 1993, pp. 321-337.

${ }^{9}$ Ibidem.

10 ***, ,An Open Letter - The Hizballah Program”, The Jerusalem Quarterly, nr. 48, 1998, URL: https://web.archive.org/web/20060821215729/http://www.ict.org.il/Articles/Hiz_letter.htm, accesat la 06.03.2021. 
(secretar general adjunct al Hezbollah, din 1992), din momentul în care organizaţia Hezbollah a fost fondată a avut trei piloni centrali: islamul reprezintă programul cel mai cuprinzător, complex și adecvat pentru o viaţă mai bună; rezistența împotriva ocupației israeliene (necesitatea materializării unei structuri jihadiste care să îndeplinească această obligație); conducătorul legitim al organizației este Teologul Jurist care este considerat succesorul profetului Mahomed și al Imamilor (poruncile și interdicțiile sale trebuie aplicate). ${ }^{11}$ Prin urmare, acești piloni reprezintă fundația Hezbollah, oferind cadrul ideologic (inspirat de Islam), un obiectiv concret (distrugerea statului Israel) și modelul ierarhic al organizației (Teologul Jurist fiind liderul suprem al organizației).

În ceea ce privește primul pilon al Hezbollah, Naim Qassem menționează 11 subcategorii ale acestuia: credința în Dumnezeul atotputernic; închinarea; autodisciplina; preocuparea pentru politică; Jihadul în numele lui Dumnezeu (,să se realizeze chiar și folosind cele mai dragi bunuri umane ale sufletului și bogăţiei fizice, fără ezitare și ori de câte ori este nevoie"); economia; responsabilitatea socială comună (,,distribuirea fondurilor de caritate - zakat pentru acoperirea nevoilor societății”); folosirea rațiunii și refuzul subordonării; comunicarea; justiția; pietatea. ${ }^{12}$ Naim Qassem menționează faptul că „Islamul reprezintă atât închinare, cât și politică, ambele aplicându-se atât în viața de pe pământ, cât și în viața de apoi, fiind relevante pentru individ și societate, deoarece atât moscheea, cât și autoritatea conducătoare, cer milă și fermitate, jihad și pace"13. Cu alte cuvinte, Qassem încearcă să argumenteze prin intermediul primului pilon, faptul că islamul reprezintă cea mai bună formă politică de organizare, deoarece reușește să combine domeniile de natură teologică, politică și socială.

Mai mult decât atât, Naim Qassem susține faptul că obiectivul final al organizației reprezintă fondarea unui stat islamic, bazat pe alegerea liberă a populației musulmane: „Când libertatea de alegere a sistemului de guvernare o să fie atribuită poporului nostru din Liban, acesta nu o să identifice o alternativă mai bună ca islamul. Așadar, solicităm implementarea unui sistem islamic bazat pe alegerea directă și liberă a populației musulmane și nu printr-o impunere forțată"14. Această idee de materializare a unui stat religios reprezintă unul dintre obiectivele organizațiilor radical religioase, iar acest deziderat poate fi atins inclusiv prin utilizarea acțiunilor teroriste. Naim Qassem încearcă să promoveze ideea conform căreia Hezbollah nu este o organizație religioasă radicală, datorită faptului că nu este dispusă să utilizeze violența pentru materializarea statului islamic. Cu toate acestea, analizând modelul Iranului (pe care Hezbollah dorește să-1 implementeze),

\footnotetext{
${ }^{11}$ Naim Qassem, Hizbullah. The Story from Within, Saqi Books, London, 2005, p. 64.

${ }^{12}$ Ibidem, pp. 67-75.

${ }^{13}$ Ibidem, pp. 75-76.

${ }^{14}$ Ibidem, pp. 81-82.
} 
poate fi observat faptul că din momentul în care statul islamic este materializat, iar instituțiile sale obțin suficientă putere pentru a controla populația, orice fel de opoziție împotriva regimului nu este acceptată.

În acest sens, în 2008, Naim Qassem a afirmat faptul că „obiectivul final al partidului, în viziunea jihadist politică și a programului de lucru, nu este posibilă în cadrul sistemului sectarian actual"15. Adevăratul motiv pentru care Hezbollah afirmă ideea materializării unui stat islamic, ca rezultat al dorinței populației, constă în faptul că liderii acesteia doresc să promoveze o imagine moderată a organizației (în cadrul comunităților non-șiite din Liban și a comunității internaționale), dar și pentru că momentan nu are încă puterea necesară pentru a-și putea impune pe deplin voința în Liban.

Astfel, pentru a putea să-și atingă obiectivele militare și politice în Liban, Hezbollah trebuie să câștige sprijinul populației. Hezbollah a reușit să-și crească influența în Liban prin intermediul exploatării principiului menționat anterior, „responsabilitate socială comună”. Prin urmare, Hezbollah derulează programe sociale dinamice (finanțate în proporție de $90 \%$ de către Iran, dar și prin intermediul donațiilor oferite de către libanezi bogați), reușind să construiască o întreagă rețea de proiecte sociale, educaționale și caritabile. Această rețea de servicii sociale include: Jihad pentru construcții (Jihad Al-Bina); Autoritatea de Sănătate Islamică; societăți de împrumut fără dobânzi; Asociația Martirilor; instituții religioase de educație. De asemenea, au fost create și instituții sportive, culturale și informaționale: centrul Khomeini, revista Al'hd, canalul TV al-Manar. ${ }^{16}$ Prin urmare, se poate observa faptul că Hezbollah a reușit să dezvolte o întreagă rețea socială, care este utilizată în principal drept un instrument de propagandă al organizației.

Investițiile importante din domeniul social pot fi înțelese ca un pas politic în cadrul strategiei Hezbollah de a fi perceput drept un actor legitim și capabil de a reprezenta interesele populației libaneze, în timp ce utilizează mijloace violente pentru materializarea obiectivelor. ${ }^{17}$ Acest argument este susținut de către afirmația lui Hassan Nassrallah (liderul Hezbollah) ,principalul scop al programelor sociale, educaționale, politice, culturale, media, pe care Hezbollah le coordonează în toate regiunile este de a-i sprijini, consolida și continua rezistența" ${ }^{18}$. Mai mult, pentru a reuși să atragă simpatia poporului libanez din alte confesiuni decât cea șiită, Hezbollah le permite și acestora accesul la facilități sociale. De altfel, capabilitățile

\footnotetext{
${ }^{15}$ Lina Khatib, „Hizbullah`s Political Strategy”, în Survival: Global Politics and Strategy, vol. 52, nr. 2, 2011, pp. 61-76.

${ }^{16}$ Mariam Farida, „Field Notes on Hizbullah`s Recruitment, Training and Organisational Structure, în Journal of Policing, Intelligence and Counter Terrorism, vol. 5, nr. 2, pp. 71-72.

${ }^{17}$ Daniel Meler, „(B)ordering South Lebanon: Hizbullah`s Identity Building Strategy”, în Journal of Borderlands Studies, 2015, pp. 1-13.

${ }^{18}$ Adham Saouli, „Hizbullah în the Civising Process: anarchy, self-restraint and violence”, în Third World Quarterly, vol 32, nr. 5, 2011, pp. 925-942.
} 
sociale controlate de către Hezbollah au un rol important în creșterea numărului de membri ai organizației. Într-o țară săracă, precum Libanul, membrii Hezbollah primesc 150-200 de dolari pe lună, educație și asistență sanitară gratuită pentru ei și membrii familiei, având un statut social superior majorităţii cetățenilor libanezi. ${ }^{19}$

Al doilea pilon al Hezbollah este reprezentat de materializarea conceptului de jihad (război sfânt). În primul rând, Naim Qassem acceptă existența a două tipuri de jihad: cel militar (îndreptat împotriva necredincioșilor) și cel al sufletului (reprezentând lupta credincioșilor împotriva naturii lor păcătoase) ${ }^{20}$. În ceea ce privește acest subiect, Naim menționează faptul că „Jihadul sufletului reprezintă provocarea mai mare, deoarece este o luptă zilnică și permanentă, între virtute și viciu, precum și între ascultarea de Dumnezeu și impulsurile sufletului. Lupta împotriva inamicului este un test mai ușor, deoarece trebuie purtată doar în situații specifice, ca parte a triumfului principiilor, moralei, dreptății, atunci când națiunea se confruntă cu opresiune, ocupație și umilință"21. Prin urmare, în conformitate cu viziunea lui Naim Qassem, cele două noțiuni de jihad sunt complementare și obligatorii pentru fiecare credincios.

În ceea ce privește jihadul militar, Naim Qassem este un adept al jihadului defensiv (presupune păstrarea independenței țărilor musulmane și expulzarea străinilor, precum și faptul că orice teritoriu capturat vreodată de islam aparține acestuia pentru eternitate, iar un atac asupra unei țări, care a fost odată musulmană deși nu mai este așa, este considerat defensiv și poate fi efectuat și de către indivizi, nu doar de militari organizați), afirmând faptul că „Acesta este modul prin care musulmanii își apără teritoriile și poporul când se confruntă cu agresiunea și ocupația. Acest mod de acțiune nu este doar legitim, ci reprezintă și o datorie"22. De asemenea, Naim Qassem evidenţiază faptul că ,în aceeaşi măsură în care îndeplinirea jihadului duce la dobândirea onoarei și libertăţii, abandonarea lui duce la rușinea și dizgrația individului și națiunii’”23. Aceste afirmații evidențiază foarte clar faptul că acest concept al jihadului militar este cel mai important pilon ideologic al Hezbollah.

Un alt subiect abordat de către Naim Qassem este cel al martirajului: „Observăm faptul că un număr mare de credincioși speră să li se asigure o misiune de martiri, ca parte a dorinței lor de a-i face pe plac lui Dumnezeu și de a câș̦tiga acceptarea Sa, ascultând voia Sa. Această dorință este doar un rezultat al cultivării lor spirituale, un produs al închinării religioase active”24 și „Martirajul reprezintă

\footnotetext{
${ }^{19}$ Daniel Byman, op.cit., p. 89.

${ }^{20}$ Naim Qassem, Hizbullah. The Story from Within, Saqi Books, Londra, 2005, pp. 85-86.

${ }^{21}$ Idem.

${ }^{22}$ Ibidem, p. 94.

${ }^{23}$ Idem.

${ }^{24}$ Ibidem, p. 102.
} 
manifestarea supremă a sacrificiului de sine, o formă de confruntare cu inamicul în cadrul liniilor directoare clare și legitime ale Shari'a"25. Pentru o înțelegere mai bună a conceptului de martiraj în concepția islamică, trebuie să evidențiem faptul că unul dintre principalele obiective ale organizațiilor teroriste radicale, precum Hezbollah, este reprezentat de dorința de a eradica „necredincioșii” (musulmani care nu își mențin tradiția sau reprezentanți ai altor religii) ${ }^{26}$

Naim Qasem extinde implicațiile conceptului de jihad militar și asupra femeilor, susținând faptul că ,unele femei au cerut permisiunea de a purta arme și de a participa direct în cadrul luptelor. Totuși, poruncile religioase nu solicită această formă de sacrificiu din partea femeilor, având în vedere numărul suficient de bărbați care pot îndeplini această sarcină, fapt care face inutilă participarea directă a acestora în luptă. Rolul femeilor în acest context se află într-un plan secund, prin oferirea de sprijin și recrutare. Acest lucru este considerat mai potrivit, având în vedere capacitățile fizice ale unei femei și împărțirea responsabilităților între ea și bărbat. Dar, răsplata femeilor din partea lui Dumnezeu nu este diminuată, ele își îndeplinesc porunca religioasă din poziţia lor’27. Prin urmare, în viziunea Hezbollah, toți membrii comunității trebuie să contribuie la îndeplinirea jihadului militar. Astfel, calitatea de membru al Hezbollah este conferită de dorința membrilor săi de a participa la jihadul militar. În acest sens, din cauza rigidităţii sale ideologice, organizația Hezbollah nu poate fi reformată, abandonarea conceptului de jihad militar ar presupune dezintegrarea acesteia.

Al treilea pilon al Hezbollah se referă la jurisprudența Teologului-Jurist (al-Wali al-Faqih). În ceea ce privește acest subiect, Naim Qassem îl citează pe Imamul Khamenei privind necesitatea existenței acestei funcții ,Scopul unei custodii absolute deținute de către Teologul-Jurist (care îndeplinește toate calificările), se referă la faptul că societatea islamică are nevoie de un orator, un jurist și un lider care să protejeze națiunea musulmană împotriva dușmanilor săi, dar asigurând și mijloacele pentru dezvoltarea culturală politică și socială a credincioșilor”28. Subordonarea față de liderul suprem al Iranului este menționată și în programul Hezbollah „Noi suntem fiii comunității musulmane (umma), partidul lui Dumnezeu, a cărei avangardă a ieșit învingătoare în Iran” și „Respectăm ordinele unui lider înțelept și drept, care îndeplinește toate condițiile necesare: Ruhollah Musawi Khomeini" ${ }^{\prime 29}$.

\footnotetext{
${ }^{25}$ Ibidem, p. 107.

${ }^{26}$ Gregg Heather, „Defining and Distinguishing Secular and Religious Terrorism”, în Perspectives on Terrorism, vol. 8, nr. 2, 2014, pp. 36-51.

${ }^{27}$ Naim Qassem, op. cit., p. 105.

${ }^{28}$ Ibidem, p. 115.

29 ***, „An Open Letter - The Hizballah Program”, The Jerusalem Quarterly, nr. 48, International Institute for Counter-Terrorism, 1998, URL: https://web.archive.org/web/20060821215729/http:// www.ict.org.il/Articles/Hiz_letter.htm, accesat la 06.03.2021.
} 
Mai mult decât atât, Naim Qassem susține faptul că Teologul-Jurist are autoritatea de a decide în probleme privind războiul și pacea, dar și trasează direcțiile de acțiune privind materializarea statului islamic. ${ }^{30}$ În conformitate $\mathrm{cu}$ acest argument, Teologul-Jurist este urmașul profetului Mohamed, fiind infailibil și reprezentând autoritatea supremă a credincioșilor pe pământ. Prin urmare, putem să concluzionăm că nu există o distincție între conducerea religioasă și politică a organizației Hezbollah.

\section{Hezbollah și Occidentul}

Din punctul de vedere al modului în care statele occidentale se poziționează în raport cu Hezbollah, se poate observa că doar unul dintre cei doi actori reușește să-și implementeze strategia cu succes.

Una dintre greșelile decidenţilor politici occidentali privind relația dintre Hezbollah și statul Israel rezidă în faptul că aceștia încearcă să promoveze o soluție de compromis prin intermediul căreia să obțină un acord între cei doi actori. Această abordare naivă este implementată de către politicienii occidentali, din cauza faptului că aceștia consideră că Hezbollah este un actor care poate să accepte o soluție de compromis în raport cu realitatea politică.

Dar Hezbollah acționează în conformitate cu logica jihadistă, conform căreia organizația trebuie să-și materializeze obiectivele fără a face compromisuri. Prin urmare, Hezbollah nu dorește să accepte o soluție de compromis cu Israelul, iar acest fapt reiese foarte clar din programul organizației. „Principala noastră premisă în lupta împotriva Israelului constă în faptul că entitatea sionistă a avut un caracter agresiv încă de la începuturile sale și construiește pe terenuri smulse de la proprietarii lor, în detrimentul drepturilor poporului musulman. Prin urmare, lupta noastră se va termina doar în momentul în care această entitate o să fie distrusă. Nu recunoaștem niciun tratat cu aceasta, niciun acord de încetare a focului și de pace, separate sau consolidat" ${ }^{\prime 1}$. Astfel, având în vedere faptul că Hezbollah a declarat jihad Israelului, nu poate fi implementată o soluție de compromis care să-i convingă pe liderii acestei organizații să renunțe la acțiunile agresive. Într-adevăr, Hezbollah poate să-și oprească atacurile împotriva Israelului pentru o perioadă scurtă de timp sau să reducă intensitatea acestora, dar doar în cazul în care se află într-o situație critică și are nevoie de timp să-și revină.

Deși decidenții occidentali au dileme majore privind modul în care trebuie să se raporteze la Hezbollah, liderii acestei organizații teroriste înțeleg perfect mecanismele de negociere ale statelor occidentale. Naim Qassem susține că percepția Occidentului în raport cu Hezbollah s-a schimbat, iar guvernele occidentale au

${ }^{30}$ Naim Qassem, op. cit., 2005, p. 117.

$31 * * *$, ,An Open Letter - The Hizballah Program”, op. cit. 
început să caute motive pentru îmbunătățirea relațiilor bilaterale. Mai mult decât atât, majoritatea guvernelor europene au refuzat să includă organizația Hezbollah pe lista organizațiilor teroriste. ${ }^{32}$

Această situaţie este generată de faptul că politicienii occidentali preferă să mențină o distincție între ramura politică și cea militară a Hezbollah. În cadrul reprezentării lor, aceștia consideră că Hezbollah este un partid politic legitim, compus din politicieni moderați care sunt dispuși să accepte soluții de compromis. Pe de altă parte, decidenții politici occidentali cred că acțiunile teroriste implementate de către Hezbollah sunt în mod exclusiv rezultatul facțiunii militare, dar care reprezintă o minoritate în raport cu facțiunea politică moderată. Această confuzie este evidențiată de către Naim Qassem, care afirmă faptul că puterile occidentale stabilesc „relații cu Hezbollah distingând două secțiuni diferite care nu există de fapt - așa-numitele aripi politice și militare -, deoarece partidul este prin natura sa, unificat" ${ }^{33}$. De asemenea, Naim Qassem afirmă faptul că „toate acțiunile politice, sociale și jihadiste sunt asumate de către conducerea organizației. Aceeași conducere care direcționează activitatea parlamentară și guvernamentală, conducând și acțiunile jihadiste în lupta împotriva Israelului' ${ }^{\prime 3}$. Prin urmare, Hezbollah trebuie să fie percepută ca o singură organizație, care utilizează mijloace politice, militare și sociale pentru atingerea obiectivelor sale.

Mai mult decât atât, liderii Hezbollah încearcă să inoculeze liderilor occidentali ideea conform căreia, organizația lor este un actor independent în raport cu Iranul. Aceștia consideră că „Hezbollah își desfășoară activitatea în Liban și nu acționează pentru materializarea unor interese regionale sau internaționale" 35 , dar acest lucru este imposibil, deoarece Teologul-Jurist este atât conducătorul suprem al Iranului, cât și liderul de facto al Hezbollah. Cu toate acestea, având în vedere reputaţia Iranului în cadrul comunității internaționale, asocierea oficială a Hezbollah cu acest stat ar determina discreditarea totală a organizației din cauza faptului că ar fi percepută doar ca un instrument al decidenților politici și militari iranieni prin care aceștia încearcă să-şi mărească influența în Orientul Mijlociu și nu ca un actor legitim care reprezintă interesele populației șiite din Liban.

Un alt aspect regăsit în cadrul abordării politicienilor occidentali este presupunerea conform căreia inițierea și intensificarea negocierilor diplomatice cu Hezbollah reprezintă o strategie de succes prin intermediul căreia îi pot convinge pe liderii acestei organizații să renunțe la utilizarea violenței. Limitările acestei abordări este evidențiată de către unul dintre mottourile organizației, care

${ }^{32}$ Naim Qassem, „Hezbollah: Islamist Resistance Comes of Age”, în New Perspective Quarterly, 2009, pp. 8-11.

${ }^{33}$ Idem.

${ }^{34}$ Idem.

${ }^{35}$ Idem. 
menționează faptul că „Armele Hezbollah sunt parte a rezistenței, nu sunt separate de aceasta" ${ }^{36}$. Problema majoră pentru decidenții politici occidentali în ceea ce privește menținerea unui dialog diplomatic cu Hezbollah constă în faptul că aceștia refuză să condamne în mod explicit acțiunile teroriste ale organizației.

Pentru a analiza perspectiva Hezbollah privind negocierile cu Occidentul trebuie să analizăm afirmația lui Naim Qassem: „Suntem dispuși să negociem cu Occidentul, atâta timp cât ambele părți au un statut egal și dialogul nu este superficial" ${ }^{37}$. Prin urmare, nu este suficient ca liderii occidentali să trateze cu indulgență acțiunile Hezbollah, dar trebuie să recunoască legitimitatea obiectivelor organizației. Abordarea Hezbollah nu este originală, aceasta a fost iniţial implementată cu succes de către Arafat privind emanciparea Organizației pentru Eliberarea Palestinei ca actor legitim în cadrul comunității internaționale. Astfel, Hezbollah încearcă să creeze o imagine moderată a organizației în cadrul comunității internaționale, susținând faptul că reprezintă interesele poporului libanez și că există posibilitatea materializării unei soluții de compromis privind relația sa cu Israelul (care este denunțat ca un stat opresiv, ale cărui interese geopolitice contravin intereselor naționale ale Libanului), dacă decidenții politici israelieni sunt dispuși să accepte anumite concesii. Cu toate acestea, chiar dacă Israelul ar face astfel de compromisuri, Hezbollah nu și-ar schimba politica, profitând doar de noile beneficii pentru a solicita alte concesii din partea autorităților israeliene, fără a onora propriile angajamente.

Mai mult decât atât, lipsa implementării unui mecanism coercitiv de către comunitatea internațională împotriva Iranului permite existența unui climat optim pentru dezvoltarea organizației „Este bine pentru îmbunătățirea poziției Hezbollah să câștige sprijin internațional, datorită faptului că poate să-și mărească numărul de membri și determină creșterea simpatiei populației față de partid"38. Astfel, faptul că majoritatea statelor occidentale preferă să tolereze acțiunile implementate de Hezbollah, permit acestei organizații să-și extindă influența în Liban și să devină un important actor nestatal în cadrul complexului regional de securitate din Orientul Mijlociu.

De asemenea, un aspect important pe care doresc să-l evidențiez constă în percepția greșită a liderilor occidentali, referitor la faptul că acțiunile ostile promovate de către Hezbollah sunt îndreptate exclusiv împotriva Israelului. În cadrul programului Hezbollah este menționat faptul că: „Noi percepem Israelul ca fiind avangarda Statelor Unite ale Americii în lumea noastră islamică. Trebuie să luptăm împotriva acestui inamic până primește ceea ce merită" 39 . Putem deduce

\footnotetext{
${ }^{36}$ Idem.

${ }^{37}$ Idem.

${ }^{38}$ Idem.

$39 * * *$, ,An Open Letter - The Hizballah Program”, op. cit.
} 
din această afirmație faptul că Israelul este perceput ca fiind o extensie a lumii occidentale în Orientul Mijlociu și din acest motiv trebuie distrus. Nu trebuie să uităm faptul că în cadrul retoricii promovate de către liderii de la Teheran și preluată de Hezbollah, Statele Unite ale Americii sunt percepute ca fiind „Marele Satan”, iar Israelul „Micul Satan”. Prin urmare, unul dintre motivele pentru care Hezbollah a declarat jihad Israelului constă în faptul că acest stat promovează principii asociate culturii occidentale (secularism, democrație etc.). Hezbollah nu este preocupat doar să distrugă Israelul, ci își dorește și să elimine influența occidentală din Orientul Mijlociu.

Liderii occidentali preferă să se delimiteze de acțiunile militare ale Israelului îndreptate împotriva Hezbollah (care consideră că singura soluție pentru a termina acest război este distrugerea Israelului), considerând că o astfel de strategie le-ar conferi poziția de mediatori. Totuși, după cum am menționat mai sus, această abordare este greșită, din cauza faptului că liderii Hezbollah percep Occidentul ca pe un inamic. Astfel, singura soluție eficientă care poate conduce la stabilizarea dinamicilor de securitate din această regiune constă în cooperarea deplină dintre Israel și statele occidentale pentru a neutraliza amenințarea reprezentată de Hezbollah.

$\mathrm{Cu}$ toate acestea, decidenții politici occidentali consideră că islamul politic promovat de către Hezbollah nu reprezintă în mod necesar o amenințare. Din acest motiv nu este greu de înțeles afirmația lui Naim Qassem despre islamul politic „Coranul ne reamintește adevărurile vechi, deja cunoscute de noi toți. Astfel, pentru ca oamenii să conviețuiască împreună cu succes, o societate trebuie să practice compasiunea, dreptatea și echitatea" ${ }^{40}$. Prin urmare, Naim Qassem creează o narațiune falsă despre implicațiile conceptului de islam politic.

Din nefericire, Naim Qassem omite intenționat să menționeze rolul central al jihadului din cadrul conceptului de islam politic. Dacă analizăm Coranul, putem observa faptul că utilizarea violenței împotriva populației nonmusulmane este încurajată și chiar răsplătită de către Allah. În conformitate cu prevederile Coranului, necredincioșii trebuie să fie pedepsiți pentru ignorarea mesajului lui Allah, transmis de către profetul Mohamed. ${ }^{41}$ Mai mult decât atât, uciderea necredincioșilor se face sub îndrumarea divină, iar credinciosul este doar o unealtă: „Nu voi credincioșii i-ați ucis, ci Allah a făcut acest lucru"42. De asemenea, nu poate exista un armistițiu definitiv între credincioși și necredincioși ${ }^{43}$ Bineînțeles, putem considera faptul că aceste versete coranice nu mai sunt relevante, sau putem merge chiar mai departe,

${ }^{40}$ Qassem Sheik Naim, „Hezbollah: Islamist Resistance Comes of Age”, în New Perspective Quarterly, 2009, pp. 8-11.

${ }^{41}$ Qur`an, Capitolul 8, URL: https://quran.com/8, accesat la 06.03.2021.

${ }^{42}$ Idem.

${ }^{43}$ Idem. 
afirmând că în prezent conceptul de jihad este asociat doar cu lupta interioară și nu mai prevede utilizarea violenței împotriva necredincioșilor.

$\mathrm{Cu}$ toate acestea, analizând programul și acțiunile Hezbollah, observăm faptul că jihadul militar reprezintă fundația ideologică a acestei organizații. De asemenea, pentru a putea percepe adevăratul înțeles al conceptului de islam politic asumat de către Hezbollah, tot ce trebuie să facem este să analizăm comportamentul Iranului după anul 1979. Astfel, se poate observa faptul că jihadul a fost utilizat atât pentru represiunea internă (împotriva oricărei forme de rezistență - oricine se opune regimului este un necredincios), cât și împotriva dușmanilor externi (pentru combaterea secularismului occidental și Israelului).

\section{Relația dintre Iran și Hezbollah}

Din punctul de vedere al relației dintre Iran și Hezbollah trebuie să evidențiem faptul că acest parteneriat reprezintă probabil cea mai puternică și eficientă alianță din istorie, dintre un stat sponsor și un grup terorist. Iranul a contribuit decisiv la fondarea, organizarea și pregătirea Hezbollah. În schimb, Hezbollah a servit interesele iraniene, organizând operațiuni teroriste împotriva inamicilor externi ai Iranului, asasinând disidenți iranieni și promovând interesele Republicii Islamice în Orientul Mijlociu. ${ }^{44}$ În acest sens, unul dintre liderii Hezbollah a afirmat în anul 1985, faptul că „relația noastră cu Revoluția islamică [Iran] este una dintre un soldat și un comandant" ${ }^{45}$. Prin urmare, de la momentul fondării sale și până în prezent, Hezbollah s-a aflat sub tutela Iranului.

$\mathrm{Cu}$ toate acestea, Naim Qassem încearcă să argumenteze faptul că relația dintre Iran și Hezbollah nu este bazată pe subordonare, fiind de fapt un parteneriat bazat pe obiective comune: „Relația dintre Hezbollah și Iran a fost stabilită prin eforturile partidului de a folosi această experiență inovatoare în regiune și de a asigura un campion în lupta împotriva Israelului. Alegerea Iranului pentru un guvern republican islamic a coincis cu principiile islamice asumate de către Hezbollah. Astfel, există o relație de armonie între Hezbollah și Iran privind programele teoretice asumate, deși aplicarea detaliată a acestora se face în raport cu particularitățile fiecărei țări în cauză" ${ }^{46}$ După cum s-a menționat mai sus, promovarea acestei narațiuni are rolul de a crește legitimitatea Hezbollah în Liban, precum și în cadrul comunității internaționale, dar nu reprezintă realitatea politică.

Una dintre principalele motivații pentru care liderii de la Teheran au susținut Hezbollahul a fost în contextul dorinței lor de răspândire a revoluției islamice în Orientul Mijlociu (prin organizarea grupurilor radicale de șiiți). Promovarea

\footnotetext{
${ }^{44}$ Daniel Byman, op.cit., p. 79.

${ }^{45}$ Ibidem, p. 90.

${ }^{46}$ Naim Qassem, op. cit., 2005, p. 236.
} 
revoluției era un mijloc prin care Iranul dorea să iasă din izolarea diplomatică în care intrase după revoluția din 1979 (aspect care a influențat reorientarea politicii sale externe și de securitate), precum și pentru a crește legitimitatea internă a noului său regim. De altfel, justificările teologice ale Revoluției din Iran au subliniat ideea răspândirii islamului politic dincolo de granițele statului iranian, Ayatollahul Khomeini declarând că „Trebuie să încercăm să răspândim revoluția noastră în lume...noi [trebuie] să confruntăm lumea cu ideologia noastră" ${ }^{\prime 4}$. Privind retrospectiv, putem să evidențiem faptul că din punctul de vedere al exportării revoluției islamice în Orientul Mijlociu, regimul de la Teheran a eșuat. Cu toate acestea, Hezbollah poate fi considerat un experiment de succes, datorită faptului că această organizație a acceptat autoritatea liderilor iranieni, precum și obiectivul de a pune bazele unui stat islamic în Liban (după modelul iranian).

Această viziune este împărtășită și de către Naim Qassem, care consideră că Revoluția Islamică a avut un impact pozitiv asupra Orientului Mijlociu, datorită faptului că a contribuit la emanciparea unui regim islamic în Iran, dar a contribuit și la declinul influenței occidentale în această regiune: „De asemenea, există o relație de armonie privind convingerile Hezbollah și abordarea Republicii Islamice în Iran, prin schimbarea pe care a adus-o pe harta regiunii prin independență de subordonare către Occident și adoptarea unei versiuni islamice promițătoare"48. Mai mult decât atât, o altă dovadă a relației strategice a Iranului cu Hezbollah este reprezentată de afirmația clericului șiit iranian Mohtashemi: „Relația dintre Hezbollah și regimul iranian depășește simpla relație a unui regim revoluționar cu o organizație revoluționară care există în afara granițelor Iranului. Este destul de evident faptul că Hezbollah reprezintă o parte din regimul iranian și un factor major în cadrul instituțiilor sale militare și de securitate"49.

Pentru atingerea obiectivelor sale în Liban, dar și în alte state din Orientul Mijlociu în cadrul cărora Hezbollah își desfășoară activitatea, Iranul a fost dispus să ofere acestei organizații sprijin militar, suport financiar și organizațional, dar și alte numeroase forme de asistență. ${ }^{50}$ Unii dintre liderii libanezi, precum Walid Jumblatt și Samir Geagea suș̦in faptul că, Hezbollah servește ca un instrument ,al proiectului ambițios al Iranului în regiune privind combaterea Israelului și, când este necesar, a Occidentului" ${ }^{51}$. Acțiunile Hezbollah au ca obiectiv destabilizarea Orientului Mijlociu și, implicit, a Libanului (pentru a putea controla mai ușor acest

\footnotetext{
${ }^{47}$ Daniel Byman, op. cit., p. 92.

${ }^{48}$ Naim Qassem, Hizbullah, The Story from Within, Saqi Books, London, 2005, p. 123.

${ }^{49}$ Ohannes Geukjan, "Which State for Lebanon in the Aftermath of the Hizbullah Israeli War of July-August 2006? A Critical Analysis", în Critical Middle Eastern Studies, vol. 17, nr. 2, 2008, pp. 135-153.

${ }^{50}$ Daniel Byman, op. cit., p. 87.

${ }^{51}$ Ohannes Geukjan, op. cit.
} 
stat), pentru a menține un climat de insecuritate care ar favoriza creșterea influenței politice și militare a Iranului în regiune.

Un alt motiv important pentru care Iranul sprijină Hezbollah se datorează considerentelor strategice. Astfel, Hezbollah luptă împotriva inamicilor Iranului (Israelul și alte puteri occidentale), acționând ca un actor proxy al Teheranului în Orientul Mijlociu. Pe lângă combaterea noilor duşmani ai Iranului, Hezbollah a permis Iranului să-și proiecteze puterea dincolo de granițele sale. Având în vedere faptul că Israelul reprezintă cea mai mare ameninţare pentru interesele strategice ale Iranului în regiune, liderii de la Teheran folosesc Hezbollah pentru a-și destabiliza adversarul, fără a folosi atacuri militare directe. Mai mult, sprijinul acordat Hezbollah a permis Iranului să obțină avantaje în raport cu Statele Unite ale Americii (pentru a putea elibera ostaticii americani aflați în posesia Hezbollah, decidenții politici de la Washington au fost de acord în 1985 și 1986 să furnizeze arme Iranului). ${ }^{52}$ De asemenea, Iranul, pentru a fi perceput în cadrul comunității internaționale ca un actor moderat, este reticent în a-și folosi direct puterea militară, dar se folosește de Hezbollah pentru a pune în aplicare astfel de acțiuni.

Prin urmare, având în vedere motivele menționate mai sus, poate fi observat faptul că există o relație clară de subordonare între Iran și Hezbollah (chiar dacă liderii acestei organizații preferă să utilizeze conceptul simbolic de parteneriat strategic). Astfel, acțiunile Hezbollah se află într-o stare de interdependență cu interesele Iranului în Orientul Mijlociu.

\section{Concluzii}

Pentru a înțelege acțiunile Hezbollah și rolul său în cadrul complexului regional de securitate din Orientul Mijlociu este important să identificăm principalii factori care au permis materializarea acestei organizații și pilonii săi ideologici, să analizăm relația sa cu Iranul, dar și atitudinea pe care o are în raport cu statele occidentale.

Astfel, putem să afirmăm că emergența Hezbollah a avut loc în contextul creșterii influenței radicalismului islamic din perioada anilor 1970-1990, dar și ca rezultat al fragmentării politice, sociale și religioase din Liban. De asemenea, un rol crucial în cadrul materializării Hezbollah a fost reprezentat de implicațiile revoluției din 1979 din Iran, deoarece noua conducere de la Teheran a căutat să sprijine comunitățile șiite aflate în proximitatea sa și să le transforme în agenți proxy, furnizându-le arme, instruire, inspirație și bani. Nu în ultimul rând, invazia Libanului din 1982 de către trupele israeliene a condus la radicalizarea comunităților șiite din această regiune, permițând organizației Hezbollah să-și crească influența în regiune.

${ }^{52}$ Ibidem, p. 96. 
În ceea ce privește pilonii ideologici ai organizației, trebuie să îi menționăm pe cei mai importanți: credința în islam, jihadul și Teologul-Jurist. Prin intermediul primului pilon, liderii Hezbollah încearcă să argumenteze faptul că islamul reprezintă cea mai bună formă politică de organizare deoarece reușește să îmbine domeniile teologic, politic și social. Prin cel de-al doilea pilon, liderii Hezbollah doresc să adopte jihadul ca instrument de rezistență împotriva Israelului și a influenței occidentale în Orientul Mijlociu. Al treilea pilon reprezintă subordonarea oficială a Hezbollah în raport cu liderul suprem al Iranului.

Având în vedere pilonii ideologici ai organizației, putem să înțelegem strategia de negociere implementată de către Hezbollah în raport cu statele occidentale. Pe de o parte, liderii Hezbollah utilizează instrumente de propagandă pentru a promova o imagine moderată a organizației în cadrul comunității internaționale, din perspectiva unui actor legitim care dorește să promoveze interesele populației șiite libaneze. Pe de altă parte, liderii occidentali și organizațiile internaționale încă percep partidul Hezbollah ca fiind o entitate separată față de facțiunea militară a organizației și încearcă să ajungă la o soluție de compromis cu acesta.

Dar, analizând motivațiile creării sale, ideologia sa și tipul său de relaţionare cu ceilalți actori, Hezbollah este un actor proxy al Iranului și acționează în funcție de interesele strategice ale acestuia în Orientul Mijlociu, în sensul răspândirii radicalismului islamic, combaterii influenței occidentale, atacării Israelului și destabilizării regiunii prin acțiuni care nu pot fi implementate direct de către Teheran.

\section{BIBLIOGRAFIE:}

1. ***, „An Open Letter-The Hizballah Program”, The Jerusalem Quarterly, nr. 48, 1998, URL: https://web.archive.org/web/20060821215729/http://www.ict. org.il/ Articles/Hiz_letter.htm

2. ***, Qur'an, Chapter 8, URL: https://quran.com/8

3. AARON, David, In Their Own Words: Voices of Jihad-Compilation and Commentary, RAND Corporation, 2007.

4. ADHAM, Saouli, „Hizbullah in the Civising Process: anarchy, self-restraint and violence", în Third World Quarterly, vol. 32, nr. 5, 2011.

5. BYMAN, Daniel, Deadly Connections States that Sponsor Terrorism, Cambridge University Press, 2005.

6. FARIDA, Mariam, „Field Notes on Hizbullah`s Recruitment, Training and Organisational Structure, în Journal of Policing, Intelligence and Counter Terrorism, volume 5, nr. 2, 2010.

7. GEUKJAN, Ohannes, "Which State for Lebanon in theAftermath of the Hizbullah-Israeli War of July-August 2006? A Critical Analysis", în Critique: Critical Middle Eastern Studies, vol. 17, nr. 2, vara 2008. 
8. HAMZEH, Nizar, „Lebanon's Hizbullah: From Islamic Revolution to Parliamentary Accommodation", în Third World Quarterly, vol. 14, nr. 2, 1993.

9. HEATHER, Gregg, „Defining and Distinguishing Secular and Religious Terrorism", în Perspectives on Terrorism, vol. 8, nr. 2, 2014.

10. JEROEN, Gunning; RICHARD, Jackson, „What's so religious about "religious terrorism"”, în Critical Studies on Terrorism, 2011.

11. KHATIB, Lina, „Hizbullah's Political Strategy”, în Survival: Global Politics and Strategy, vol. 53, nr. 2, 30 martie 2011.

12. LAMY, Pascal, GNESOTTO, Nicole, JEAN, Michel Baer, Where is the world going?, Editura Niculescu, București, 2018.

13. MELER, Daniel, „(B)ordering South Lebanon: Hizbullah's Identity Building Strategy", în Journal of Borderlands Studies, 2015.

14. PERI, Rosita, „Islamist Actorsfrom an Anti-system Perspective: The Case of Hizbullah", în Politics Religion and Ideology, vol.15, nr. 4, 2014.

15. QASSEM, Naim, „Hezbollah: Islamist Resistance Comes of Age”, în New Perspective Quarterly, 2009.

16. QASSEM, Naim, Hizbullah. The Story from Within, Saqi Books, London, 2005.

17. TAHERI, Amir, Holy Terror - The Inside story of the Islamic Terrorism, Sphere Books Limited, 1987. 